\title{
Reduction of Food Intake and Weight Gain by the ob Protein Requires a Specific Secondary Structure and Is Reversible
}

\author{
Klaus Giese,* Wendy J. Fantl,* Charles Vitt, ${ }^{\dagger}$ \\ James C. Stephans,* Lawrence Cousens, ${ }^{\neq}$Matthew Wachowicz, ${ }^{\neq}$ \\ and Lewis T. Williams* \\ Departments of ${ }^{*}$ Chiron Technologies, ${ }^{\dagger}$ Pharmacology, and ${ }^{\ddagger}$ Protein \\ Chemistry, Chiron Corporation, Emeryville, California, U.S.A.
}

\begin{abstract}
Background: Obesity, the condition of excessive accumulation of fat is a poorly understood disorder and is a risk factor for type II diabetes, hypertension, and hyperlipidaemia. Recently, a putative mouse obese gene was cloned and its product, termed ob protein, was shown to be involved in the regulation of body weight.

Materials and Methods: Bacterial and insect cells were used for expression of recombinant mouse ob protein. Amino-terminal sequence analysis and site-directed mutagenesis were used to identify and characterize the mature form of ob protein. Genetically obese mice and wild-type rats were used to determine the biological activity of ob protein.
\end{abstract}

Results: Mouse ob protein is synthesized as a precursor molecule, the mature form of which was found in mouse serum. Biochemical analysis identified the processing site in the ob precursor molecule and an intramolecular disulfide bond in the mature form that is necessary for activity. Reduction of food intake and weight gain after administration of ob protein to genetically obese mice and wild-type rats is reversible.

Discussion: This study demonstrates that ob protein is a secreted satiety factor which regulates body weight and reduces food intake even in animals with no genetic body weight abnormalities. The failure of ob protein to effect these parameters in $d b / d b$ mice supports the hypothesis that these mice are deficient in a signaling molecule that normally responds to the ob protein.

\section{INTRODUCTION}

Obesity is a complex disorder that is poorly understood and is a risk factor for hyperglycemia, hypothermia, and hyperinsulimea $(1,2)$. Appetite, energy balance, and body weight gain are modulated by diverse neurochemical and neuroendocrine signals from different organs in the body and specific regions of the brain $(3,4)$. In particular, changes in food intake were observed after direct administration of specific drugs in the hypothalamus, suggesting a key role of this organ in satiety and energy balance (5-7). This is supported by the findings that abnormalities or introduced lesions in the hypothalamus resulted

Address correspondence and reprint requests to: Lewis T. Williams, Department of Chiron Technologies, Chiron Corporation, Emeryville, CA 94608 , U.S.A. in an obese phenotype (7). Up until now, the identity of specific proteins/factors involved in the regulation of body weight balance was unknown.

Genetic analyses have identified six single gene mutations associated with an obese phenotype $(8-11)$. Two of these mutations, termed obese $(o b)$ and diabetes $(d b)$, have been studied in detail (reviewed in Refs. 2 and 12). Syndromes associated with these mutations resemble conditions of morbid obesity in humans $(9,10)$. Experiments in which wild-type and obese animals were surgically joined (parabiosis), suggested that $o b / o b$ mice lack a satiety hormone which regulates food consumption and weight gain, whereas $d b / d b$ mice may lack downstream signaling function $(8,13)$. Recently, a putative mouse obese gene was isolated and the mRNA 
was detected exclusively in fat tissues (10). The gene product, termed ob protein ("leptin"), was shown to be involved in the regulation of body weight (14-16). Here, we extended these studies by the identification and characterization of the active form of ob protein. We determined the processing site in the ob precursor molecule and provide evidence for a specific secondary structure in the mature form that is required for biological activity. Moreover, we show that reduction of food intake and weight gain after administration of ob protein to genetically obese mice and wild-type rats is reversible.

\section{MATERIALS AND METHODS}

\section{Cloning of Mouse ob Protein}

Coding region for mouse ob protein was obtained by reverse transcriptase-polymerase chain reaction (RT-PCR) according to the manufacturers conditions (Pharmacia, Piscataway, NJ) using polyA(+) mRNA isolated from adipose tissue, reverse primer 5'-GCGGATCCTCAGCATTCAGGGCT $A A C A T C C A A C T-3^{\prime}$ and forward primer 5'CGCATATGTGCTGGAGACCCCTGT-3', based on the published sequence (10). Sequences in italics represent nucleotides of the coding and noncoding strand which were extended either at the $5^{\prime}$ or $3^{\prime}$ end with nucleotides to create restriction enzyme sites. ob (22-167) was PCR amplified using mouse ob cDNA as template, forward primer 5'-GCTCTAGACATATGGTGCCTATCCAGA $A$ A G TCC-3', including an initiation codon for translation in bacteria, and the above-mentioned reverse primer. ob-C167A was PCR amplified as described above using reverse primer $5^{\prime}$-CGCGG ATCCTCACGCTTCAGGGCTAACATCCAACTG-3'. The fidelity of the PCR-amplified ob coding regions was verified by DNA sequencing.

\section{Expression and Purification of Recombinant ob Protein and Immunoblot Analysis}

Escherichia coli K12 strain BL21 (DE3)plys (17) was used for bacterial ob protein expression in plasmid pET (17). Plasmids pEVRF (18) was used for ob protein expression in COS-7 cells. Transient DNA transfections into mammalian cells were performed as described (19). ob protein expressed in bacteria at a level of $500 \mathrm{mg} / \mathrm{l}$ was isolated from inclusion bodies as follows: bacterial cells were disrupted by French Press in phos- phate-buffered saline (PBS), $\mathrm{pH}$ 7.5, supplemented with 1 mM EDTA (lysis buffer), and inclusion bodies washed with lysis buffer plus $1 \%$ Triton $\mathrm{X}-100$. ob protein was solubilized in $20 \mathrm{mM}$ Tris- $\mathrm{HCl}$ (pH 7.5), $10 \mathrm{mM} \mathrm{NaCl}, 7 \mathrm{M}$ urea and chromatographed on a Q-Sepharose fast flow column (Pharmacia). The ob protein was eluted with an $\mathrm{NaCl}$ gradient, adjusted to $0.2 \mathrm{mg} / \mathrm{ml}$, and dialyzed against PBS (containing $0.1 \mathrm{~g} / \mathrm{l} \mathrm{Ca} / \mathrm{Mg}$ ) overnight. Plasmid PAcC13 (20) was used for expression of ob protein in SF9 insect cells $(21,22)$. SF9 suspension cultures of 5 or $10 \mathrm{l}$ were grown in serum-free medium (23), and secreted ob protein $(10 \mathrm{mg} / \mathrm{l})$ was purified as follows: the supernatant was concentrated using $5-\mathrm{kD}$ cutoff membranes and loaded onto a DEAE-Sepharose fast flow column (Pharmacia) in $20 \mathrm{mM}$ Tris- $\mathrm{HCl}, \mathrm{pH}$ 8.0. ob protein was eluted using an $\mathrm{NaCl}$ gradient, adjusted to $30 \%$ ammonium sulfate and loaded onto a Phenyl-Sepharose fast flow column (Pharmacia) equilibrated with the same buffer. Bound protein was eluted with $20 \mathrm{mM}$ Tris- $\mathrm{HCl}, \mathrm{pH} 8.0$, concentrated and loaded onto a Sephacryl SHl00HR column (Pharmacia). Fractions containing ob protein were pooled. Overexpressed ob proteins were separated by $16 \%$ SDS-PAGE and detected by Coomassie staining or immunoblotting (24) using polyclonal rabbit antibody raised against recombinant ob protein (E. L. Labs, Soquel, CA, U.S.A.). Protein preparations were analyzed for the level of endotoxin to ensure that treated animals received less than 1 unit endotoxin/day.

\section{Intraperitoneal and Intravenous Administration of Recombinant ob Protein}

Groups of five $o b / o b$ and $d b / d b$ mice (Jackson Laboratory) age 4 to 5 weeks were injected intraperitoneally once a day over a period of 10 days with bacterially or baculovirus-expressed mature ob protein at a concentration of 0.3 and $3 \mathrm{mg} / \mathrm{kg} /$ day. Groups of four CD rats (Charles River Laboratory) age 5 to 6 weeks were injected by jugular cannulae twice a day over a period of 5 days at a protein concentration of $0.3 \mathrm{mg} / \mathrm{kg} /$ day. Control animals received saline. All rats were housed in metabolic cages for monitoring body weight, food consumption, fecal weight, water intake, and urine output. Blood and urinalysis were done daily before the first administration of ob protein to determine protein, glucose, ketones, nitrite, uribilinogen, bilirubin, $\mathrm{pH}$, and leukocyte levels. 


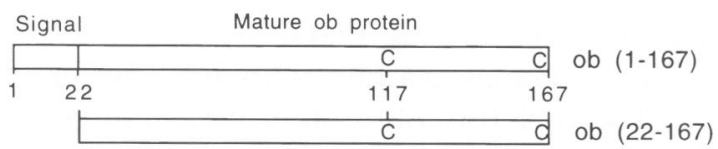

B

$$
\downarrow
$$$$
\text { A-V-P-I-Q-K-V-Q-D-D-T-K-T-L-I-K-T-I-V-T-P }
$$

C

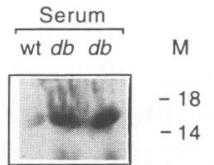

$\mathrm{D}$

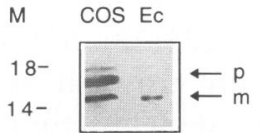

FIG. 1. Identification of a processed and secreted form of ob protein in mouse serum

(A) Schematic representation of the precursor (ob 1-167) and mature (ob 22-167) form of mouse ob protein. (B) Amino-terminal sequence of secreted, purified recombinant mouse ob protein from insect cells transfected with a full-length ob expression plasmid. The arrow indicates the cleavage site in the precursor molecule. (C) Immunoblot of sera from normal (wt) and $d b$ mice with anti-ob antibody. (D) Immunoblot of lysates from COS-7 cells transfected with mouse ob expression plasmid (COS) and bacterially expressed ob protein lacking the first 21 amino acids (Ec) with anti-ob antibody. p, precursor; $m$, mature forms of ob protein, $M$, molecular weight standards in $\mathrm{kD}$.

\section{RESULTS}

Computer-aided analysis of the $o b$ open reading frame showed that the amino-terminal 21 amino acids could function as a signal sequence allowing secretion of ob protein from its site of synthesis in the adipocyte into the bloodstream. To determine the molecular weight of mature ob protein, we performed immunoblot analysis of serum from wild-type and obese $(d b / d b)$ mice using polyclonal anti-ob antibody (Fig. 1). ob protein was detected in serum of both wild-type and $d b / d b$ mice, although levels were significantly higher in the latter. No ob protein was detected in serum from ob/ob mice (data not shown). ob protein was also detected in supernatant from differentiated pre-adipocytes after immunoblot analysis (M. Cardone, WJF, and LTW, unpublished results). The detected protein migrated with a molecular weight of $16.5 \mathrm{kD}$, which is smaller than that calculated for the ob open reading frame, suggesting that ob protein is synthesized as a precursor molecule consisting of a signal sequence and a mature form.

To further examine whether ob protein is synthesized as a precursor molecule, we expressed recombinant full-length mouse ob protein in COS-7 cells (Fig. 1D). Immunoblot analysis of lysate from transfected COS-7 cells identified two proteins. The upper protein migrated with a molecular weight predicted for the full-length precursor. The lower protein comigrated with an ob polypeptide expressed and purified from bacteria lacking the first 21 amino acids. This result strongly suggests processing of the ob precursor molecule in COS-7 cells. To identify the processing site, we expressed fulllength ob protein in insect cells which have been shown to provide a suitable eukaryotic environment to study posttranslational modifications such as signal sequence cleavage (25). Secreted ob protein was identified by immunoblot analysis in the supernatant of infected insect cells (data not shown). Purification of the secreted ob protein and subsequent amino-terminal sequence analysis identified the processing site as amino acids 21 and 22 (Fig. 1B). Thus, these data support the view that ob polypeptide is synthesized as a precursor molecule consisting of a signal sequence and a mature form which is secreted into the blood stream.

We designed experiments to determine if our purified ob protein represents the proposed blood-borne factor that regulates food intake and eating behavior $(8,13)$. To this end, we administered purified recombinant mature ob protein into $o b / o b$ animals, which lack this protein and are obese (Fig. 2). Intraperitoneal injection of $3 \mathrm{mg} / \mathrm{kg} /$ day showed a significant reduction in weight gain of $65 \%$ compared to control obese animals injected with saline ( $p$ value: $>0.01$ ) (Fig. $2 \mathrm{~A}$ and $\mathrm{C}$ ). After completion of the ob regimen, weight gain increased and was even higher $(47 \%)$ than that of control animals (Fig. $2 \mathrm{~A}$ and $\mathrm{C}$ ). These data indicate that the administration of ob protein induced a significant reduction in weight gain and, importantly, that the effect of ob protein is reversible. Administration of ob protein to $d b / d b$ animals had no effect, suggesting that these animals lack a signaling molecule that normally responds to ob protein (Fig. $2 \mathrm{~B}$ and D). The lack of response to ob protein in $d b / d b$ mice also testifies to the purity of the protein preparation, since toxic contaminants could theoretically be responsible for the observed reduction in weight gain in the $o b / o b$ mice.

To examine whether appetite suppression induced by recombinant mouse ob protein would only be detected in obese animals, we 
A

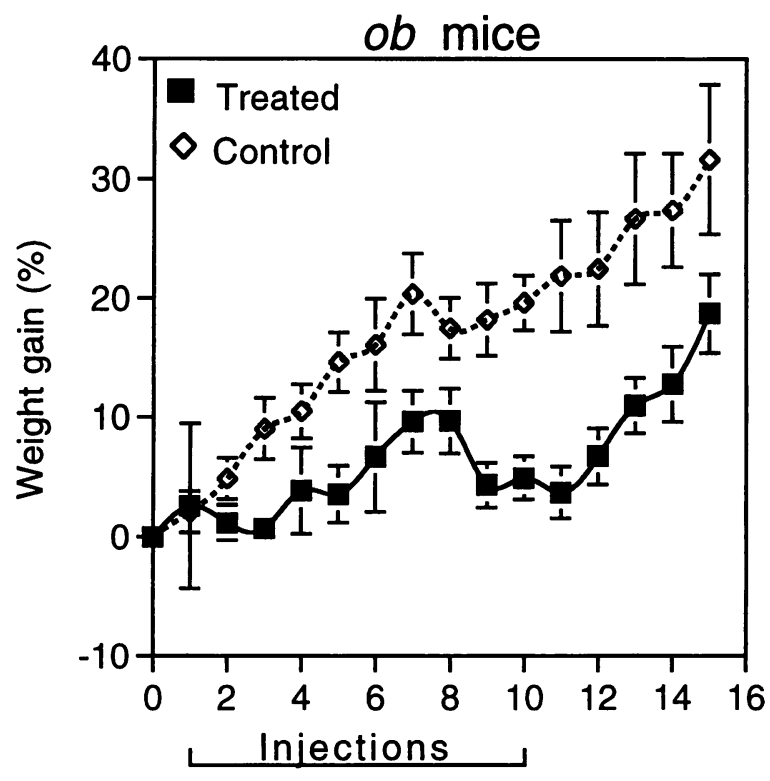

days

C

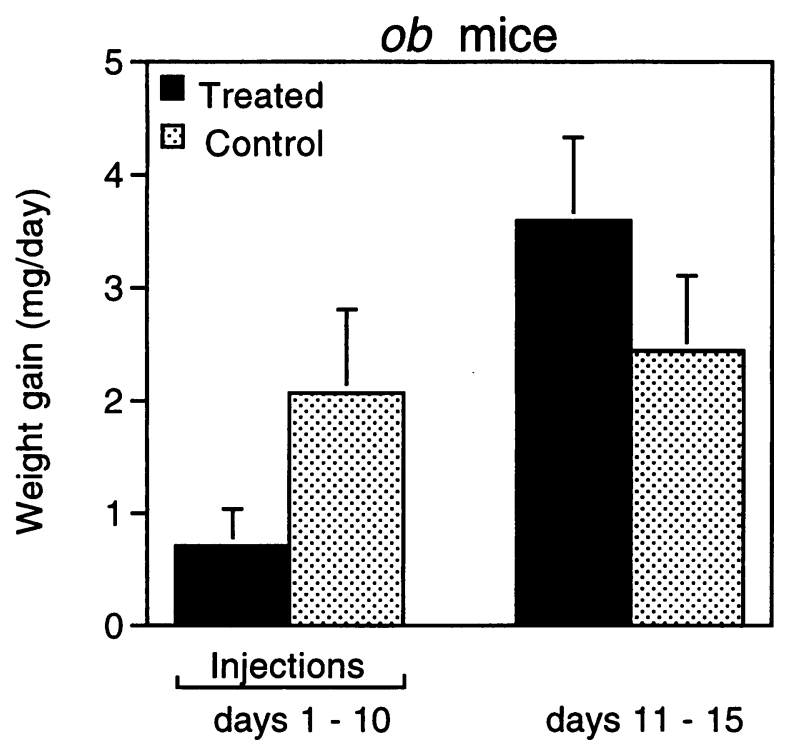

B

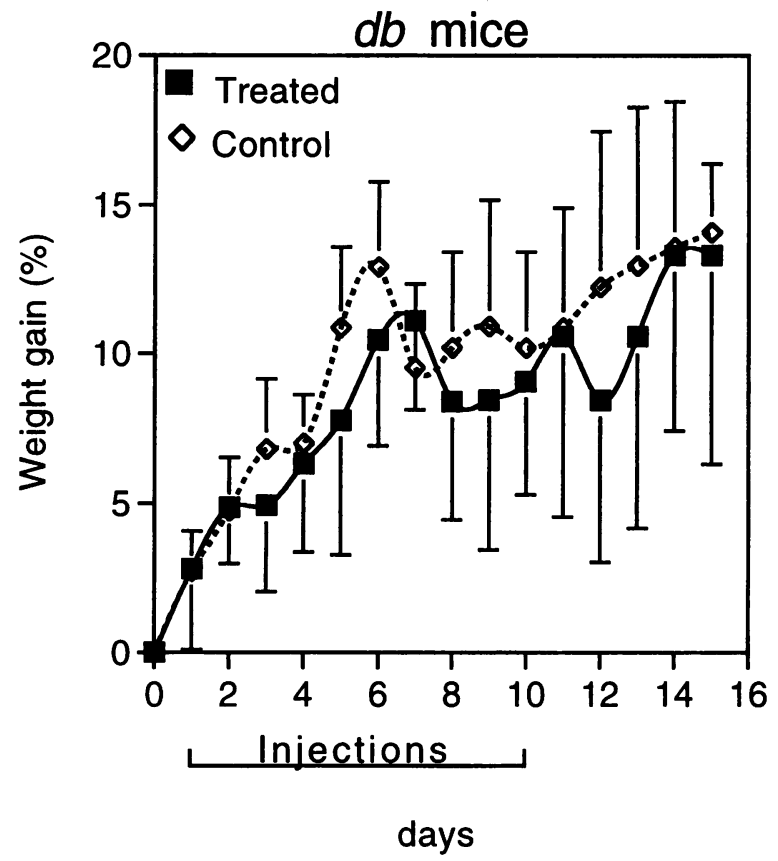

D

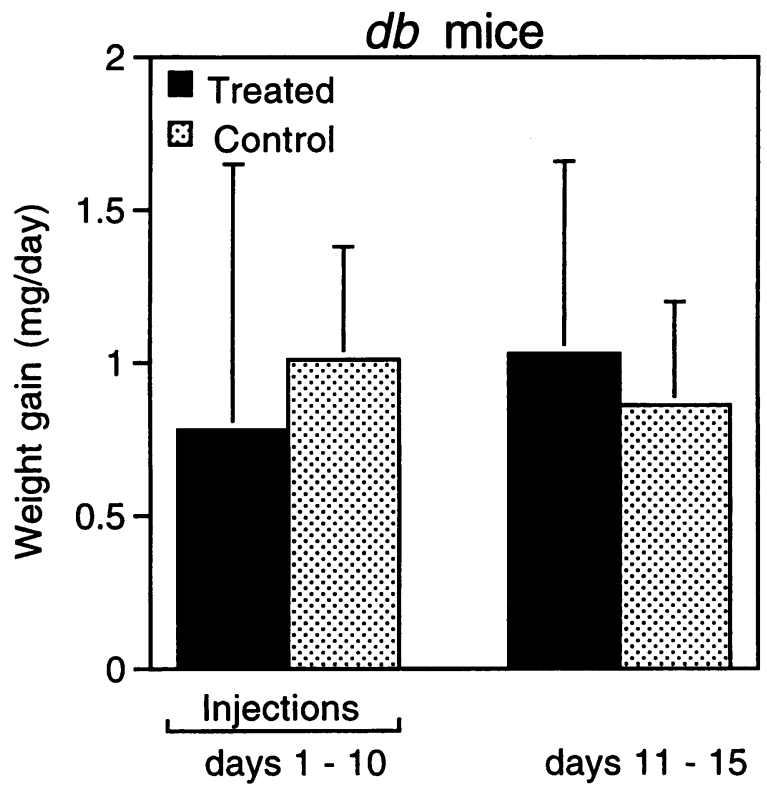

FIG. 2. Intraperitoneal administration of recombinant ob protein into genetically obese mice

(A and B) Graphs showing the average weight gain in percentage over the weight at day zero of $o b$ and $d b$ mice injected either with recombinant ob protein (solid line) or saline (dotted line). (C and D) Graphs showing weight gain in $\mathrm{mg} /$ day for the period of treatment and thereafter. The values were obtained by calculating the individual slopes for each animal from the experiments shown in Panels A and B. 
administered ob protein into wild-type rats. Intravenous delivery of ob protein at a dose of $0.3 \mathrm{mg} / \mathrm{kg}$ into wild-type rats also resulted in weight loss and reduction in food intake (Fig. 3). In injected animals almost no weight gain was detected during the 5-day period in the rats treated with recombinant ob protein compared with control rats administered with saline (Fig. $3 \mathrm{~A}$ and B). Food intake in the treated group was $30 \%$ lower than that of the control group (Fig. 3C). As with ob/ob mice, cessation of the injections resulted in weight gain that was indistinguishable from the control group (Fig. 3B).

In the course of these experiments we noticed a difference in the activities of recombinant ob protein purified from bacteria and that from insect cell supernatant. Administration of purified ob protein from insect cell supernatant at a dose of 0.3 and $3.0 \mathrm{mg} / \mathrm{kg}$ to obese and wild-type animals was more effective than bacterially expressed ob protein (Table 1 and data not shown). Treated $o b / o b$ mice gained only 18 or $31 \%$ of the weight of control animals when injected with $3.0 \mathrm{mg} / \mathrm{kg}$ ob protein purified from insect cell supernatant or bacteria, respectively. Less pronounced effects on weight gain were detected using $0.3 \mathrm{mg} / \mathrm{kg}$, indicating a dose-dependent function of this protein in obesity.

The presence of two cysteine residues in the ob primary structure raised the question of whether these amino acids might be involved in the formation of a specific secondary structure. Analysis of recombinant wild-type ob proteins by nonreducing SDS-PAGE showed a significantly faster mobility in the absence of reducing agent (Fig. 4). This increase in the mobility is characteristic of the presence of an intramolecular disulfide bond (26). To examine whether the formation of the loop structure at the $C$ terminus of ob protein is important for biological activity, we performed site-directed mutagenesis to change the cysteine at amino acid 167 to alanine. No change in the migration of this mutant ob protein, ob-C167A, was detected when analyzed by SDS-PAGE in the absence of reducing agent compared with the wild-type protein, indicating the absence of the intramolecular disulfide bond (Fig. 4). However, the mutant ob protein was able to form dimers (data not shown). Administration of ob-C167A protein at a concentration of $3 \mathrm{mg} / \mathrm{kg}$ to $o b / o b$ mice showed almost no effect in the regulation of weight gain compared with the same amount of wild-type protein (Fig. 5). Thus, these data suggest that biologically active ob protein comprises an intramolecular disulfide bond which results in a loop at the $C$ terminus consisting of 51 amino acids, and is necessary for activity.

\section{DISCUSSION}

Our findings have identified the biologically active form of ob protein and characterized its role in the regulation of food intake and body weight gain. Our data are consistent with recent reports which have shown that daily injections of recombinant ob protein into ob/ob mice lowered body weight, percentage body fat, and food intake (14-16). Administration of ob protein to wild-type mice showed only a weak effect on body weight gain $(14,15)$. Wild-type rats injected with ob protein, however, showed almost no weight gain compared with control animals (Fig. 3). One interpretation of this result is that wild-type rats are more sensitive to ob protein than wild-type mice. A different explanation might consider the method of administration. In the mice studies $(14,15)$, ob protein was administered intraperitoneally, whereas wild-type rats were injected intravenously (Fig. 3). Although both routes showed in our hands an immediate effect on the amount of weight gain and food intake (compare Figs. 2A and 3), an analysis of the pharmakokinetics of ob protein will be necessary to distinguish between the two possibilities.

The observed difference in the activity between ob protein purified from insect cells and bacteria is most likely the result of the purification protocol used. Bacterially expressed ob protein was isolated from inclusion bodies and had to be refolded, whereas ob protein purified from insect cell supernatant was soluble. Although we did not detect significant differences between both proteins in SDS-PAGE, we cannot rule out that the presence of an extra methionine residue in the bacterially expressed ob protein is responsible for the reduced activity.

Another important observation of our study is that the effect of ob protein on eating behavior is reversible. After cessation of the ob regimen, treated mice rapidly gained weight (Fig. 2 A and $C$ ). Weight gain was even higher in the treated group than in the control animals. Similar results were observed with wild-type rats. Shortly after the last injection of ob protein, weight gain of treated rats were indistinguishable from control animals (Fig. 3). These observations raise questions regarding therapeutic applica- 
A

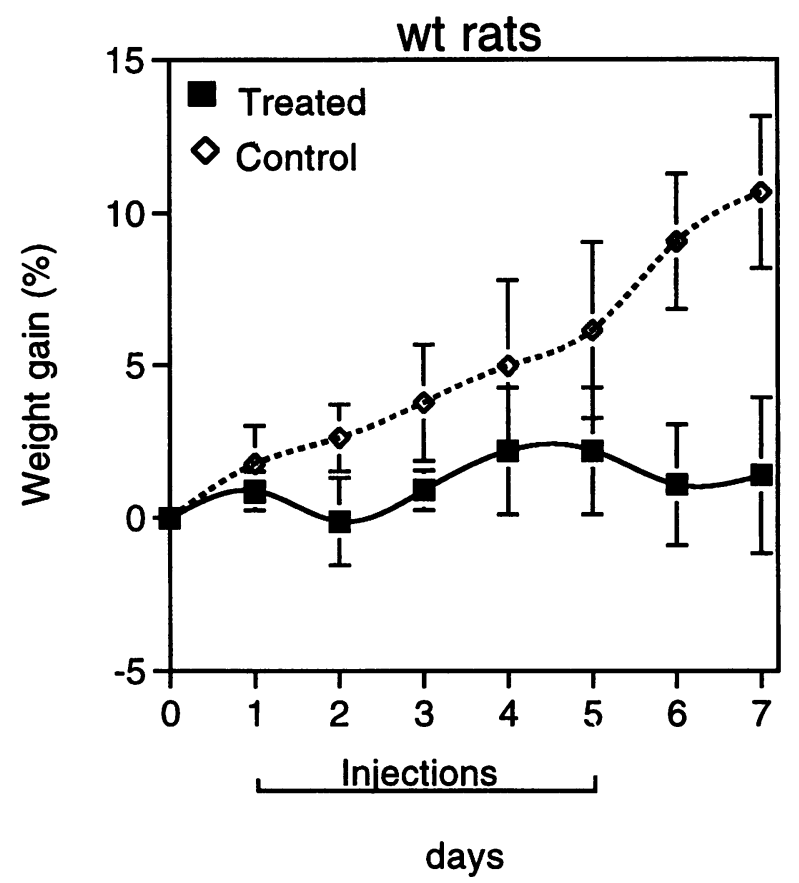

C

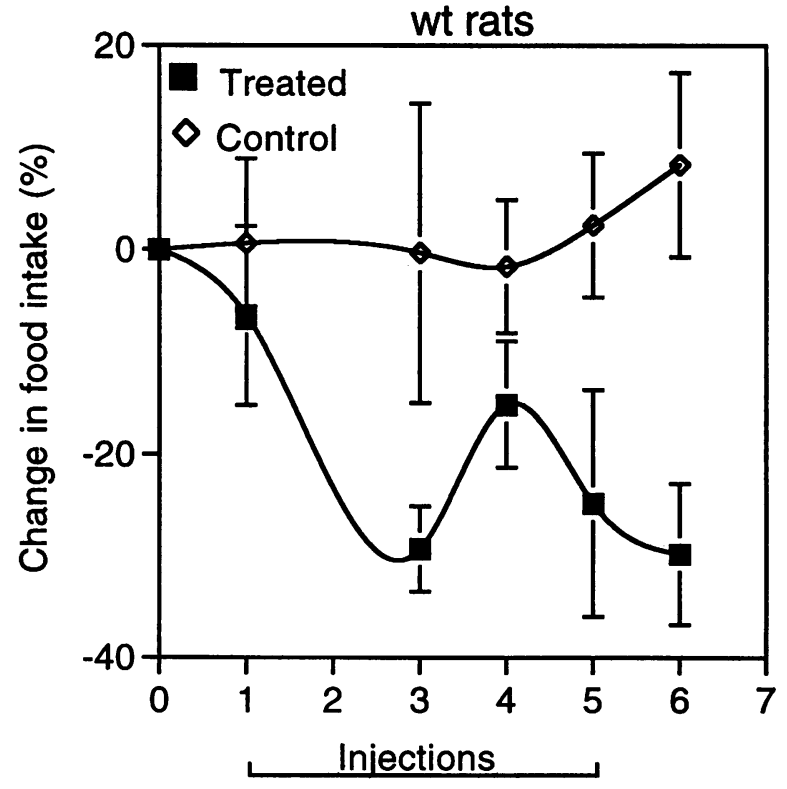

days

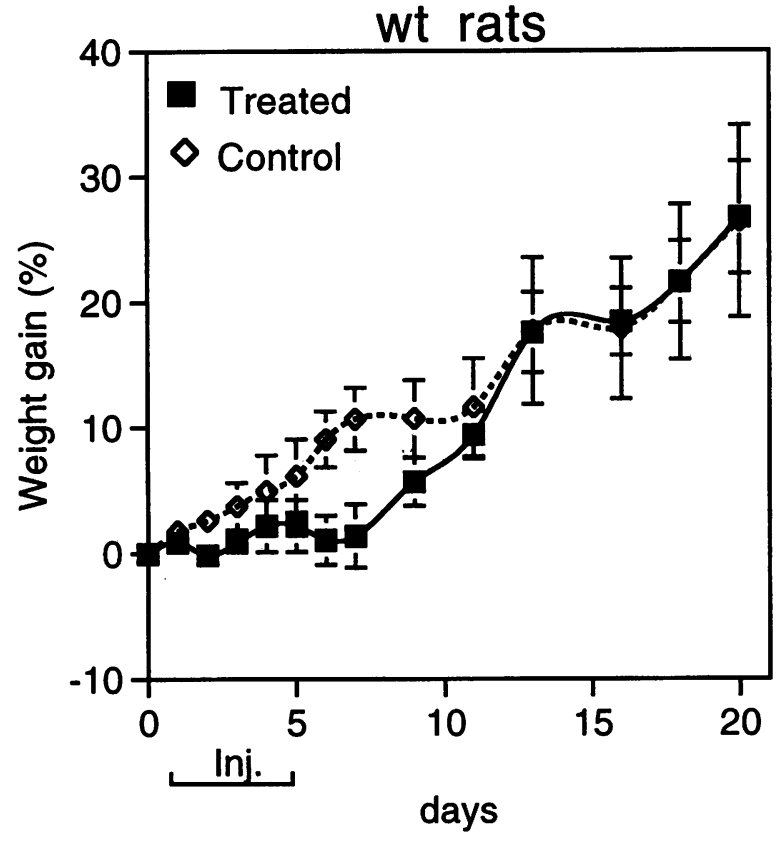

FIG. 3. Intravenous administration of recombinant ob protein to wild-type rats

(A) Graph showing the average weight gain in percentage over the weight at Day 0 of wild-type rats injected either with recombinant ob protein (solid line) or saline (dotted line). (B) Same as Panel A, but measuring weight gain over a period of 20 days. (C) Average change in food intake in percentage over the weight at Day 0 of wild-type rats injected either with recombinant ob protein (solid line) or saline (dotted line). 
TABLE 1. Effect of ob proteins on body weights of $o b / o b$ mice

\begin{tabular}{lcccccc}
\hline & & \multicolumn{4}{c}{ ob Protein (mg/kg/day) } \\
\cline { 3 - 6 } & & Saline & Bacterially Expressed & & $\begin{array}{c}\text { Baculovirus Expressed } \\
\text { (SF9 cells) }\end{array}$ \\
\cline { 3 - 6 } & & $\mathbf{0 . 3}$ & $\mathbf{3 . 0}$ & $\mathbf{0 . 3}$ & 3.0 \\
\hline Day 0 & $26.2 \pm 1.94$ & $27.6 \pm 1.85$ & $26.4 \pm 3.14$ & $27.2 \pm 1.33$ & $28.0 \pm 2.53$ \\
Day 5 & $31.0 \pm 1.26$ & $30.2 \pm 1.94$ & $28.8 \pm 2.79$ & $29.0 \pm 0.63$ & $29.6 \pm 2.24$ \\
Day 10 & $35.0 \pm 1.41^{a}$ & $32.8 \pm 2.14$ & $29.2 \pm 2.93^{a}$ & $30.6 \pm 1.10$ & $29.6 \pm 1.85^{a}$ \\
$\Delta$ weight gain & 8.8 & 5.2 & 2.8 & 3.4 & 1.6 \\
\hline
\end{tabular}

Groups of five $o b / o b$ mice were administered daily with saline or ob protein at different concentrations.

${ }^{a}$ Change in body weight in grams between control and treated animals at Day 10 was significantly different $(P<0.01)$ as determined by a nonparametric Wilcoxon test (unpaired; two-tailed).

tions of ob protein in treating obesity, especially with respect to the duration of treatment and in light of a possible desensitization of the ob receptor.

Our data confirm that ob protein functions as a satiety factor, and support previous observations with parabiosed animals $(8,13)$. In these experiments, normal mice were joined surgically with $o b / o b$ mice, and the obese animal lost weight, suggesting the presence of a soluble factor in serum of wild-type animal. The previous reports, as well as the data presented here, are highly suggestive that this soluble factor is ob. These data also give an explanation as to why $o b / o b$ mice starved to death when surgically joined to $d b / d b$ mice (8). As identified in serum from $d b / d b$ mice, ob protein was significantly

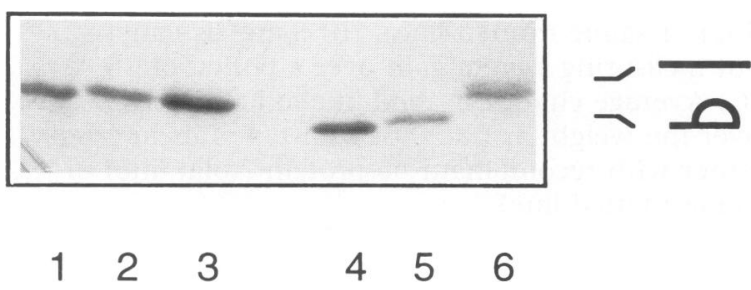

FIG. 4. Intramolecular disulfide linkage in ob protein

SDS-PAGE of recombinant mouse ob proteins in the presence (Lanes 1 to 3 ) and absence (Lanes 4 to 6) of DTT. (Lanes 1 and 4) ob protein purified from insect cells. (Lanes 2 and 5) Wild-type ob protein purified from bacteria. (Lanes 3 and 6) Mutant ob-C167A protein purified from bacteria.

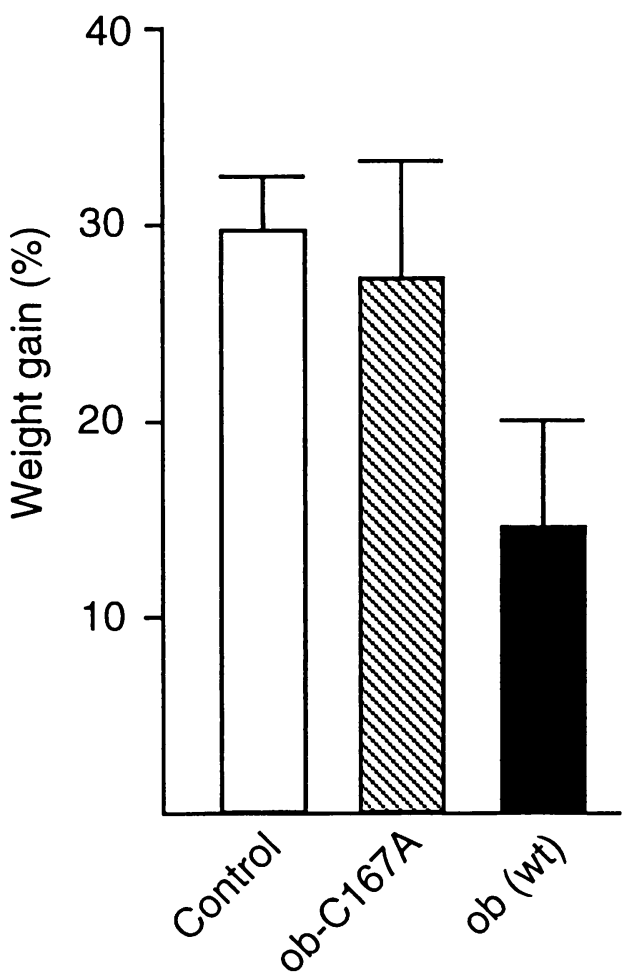

FIG. 5. Biological active ob protein requires an intra-molecular disulfide bond

Graph showing the average weight gain at Day 10 in percentage over the weight at Day 0. Groups of five $o b / o b$ mice were intraperitoneal injected with saline (open bar), $3 \mathrm{mg} / \mathrm{kg} /$ day mutant ob-C167A protein (strippled bar), or $3 \mathrm{mg} / \mathrm{kg} /$ day wild-type ob protein (black bar). Change in body weight between the control animals and the animals injected with the wild-type ob protein at Day 10 was significantly different $(P<0.01)$ as determined by a nonparametric Wilcoxon test (unpaired; two-tailed). 
up-regulated in these animals thus suppressing appetite in the $o b / o b$ animal. The increase in ob gene expression in $d b / d b$ mice suggests a feedback loop in which ob gene expression is under the control of a signaling molecule which is defective in $d b / d b$ mice. This signaling pathway includes the hypothalamus since lesions in the hypothalamus result in up-regulation of ob protein expression similar to that observed in $d b / d b$ mice (7). These data rule out a possible autoregulation of ob gene expression.

Our data and recent results from Halaas et al. (15) have confirmed that ob protein is present in serum. In addition, we determined that ob protein is synthesized as a precursor protein consisting of a 21 amino acid long signal sequence (Fig. 1C). Moreover, we identified that biologically active ob protein consists of an intramolecular disulfide bond which results in the formation of a loop structure at the $C$ terminus. A mutant form of ob protein, ob-C167A, in which the Cterminal cysteine was substituted with alanine to prevent formation of this loop structure, showed no effect on food intake and weight gain when injected into obese animals (Fig. 5). Whether this loop structure is necessary for the interaction with a putative ob receptor or is involved in stabilization of the mature protein has to be determined. Identification of the ob receptor and characterization of ob gene regulation should help define the molecular pathways that regulate satiety and metabolic changes in the obese state.

\section{ACKNOWLEDGMENTS}

The authors thank Ross Okamura (UCSF) for mouse fat tissue, Jon Strich, Frank Marcus, and Bob Drummond for help in protein production and purification, and Frank Masur and Surinder Kaur for mass spectroscopy and N-terminal sequence analysis. We thank Leah Conroy for expert assistance in growth of insect cells. We also thank Laurie Stephens, Mike Cardone, Filippo Randazzo, David Duhl, and Jaime Escobedo for helpful discussions.

\section{REFERENCES}

1. Bray BA, York DA. (1979) Hypothalamic and genetic obesity in experimental animals: An autonomic and endocrine hypothesis. Physiol. Rev. 59: 719-809.
2. Friedman JM, Leibel RL. (1992) Tackling a weighty problem. Cell 69: 217-220.

3. Grundy SH, Barnett JP. (1990) Metabolic and health complications of obesity. Diseasea-Month 36: 645-696.

4. Harris MI, Hadden WC, Knowler WC, Bennett PH. (1987) Prevalence of diabetes and impaired glucose tolerance and plasma glucose levels in U.S. population aged 20-74 yr. Diabetes 36: 523-534.

5. Woods SC, Gibbs J. (1989) The regulation of food intake by peptides. Ann. NY Acad. Sci. 575: $236-243$.

6. Bray GA, York DA, Fisler JS. (1989) Experimental obesity: A homeostatic failure due to defective nutrient stimulation of the sympathetic nervous system. Vitam. Horm. 45: 1-125.

7. Maffei M, Fei H, Lee G-H, et al. (1995) Increased expression in adipocytes of ob RNA in mice with lesions of the hypothalamus and with mutations at the $d b$ locus. Proc. Acad. Natl. Acad. USA 92: 6957-6960.

8. Coleman DL. (1973) Effects of parabiosis of obese with diabetes and normal mice. Diabetologia 9: 294-298.

9. Coleman DL. (1978) Obese and diabetes: Two mutant genes causing diabetes-obesity syndromes in mice. Diabetologia 14: 141-148.

10. Zhang Y, Proenca R, Maffei M, Barone M, Leopold L, Friedman JM. (1994) Positional cloning of the mouse obese gene and its human homologue. Nature 372: 425-432.

11. Naggert JK, Fricker LD, Varlamov O, et al. (1995) Hyperproinsulinaemia in obese fat/fat mice associated with a carboxypeptidase $\mathrm{E}$ mutation which reduces enzyme activity. Nature Genet. 10: 135-142.

12. Rink TJ. (1994) In search of a satiety factor. Nature 372: 406-407.

13. Coleman DL, Hummel KP. (1969) Effects of parabiosis of normal with genetically diabetic mice. Am. J. Physiol. 217: 1298-1304.

14. Pellymounter MA, Cullen MJ, Baker MB, et al. (1995) Effects of the obese gene product on body weight regulation in $o b / o b$ mice. Science 269: 540-543.

15. Halaas JL, Gajiwala KS, Maffei $M$, et al. (1995) Weight-reducing effects of the plasma protein encoded by the obese gene. Science 269: 543-546.

16. Campfield LA, Smith FJ, Guisez Y, Devos R, Burn P. (1995) Recombinant mouse ob protein: Evidence for a peripheral signal linking 
adiposity and central neural networks. Science 269: 546-549.

17. Studier F, Rosenberg A, Dunn J, Dubendorff J. (1990) Use of T7 RNA polymerase to direct expression of cloned genes. Methods Enzymol. 185: $60-89$.

18. Matthias $P$, Mueller $M$, Schreiber E, Rusconi S, Schaffner W. (1989) Eukaryotic expression vectors for the analysis of mutant proteins. Nucleic Acids Res. 17: 6418-6418.

19. Grosschedl R, Baltimore D. (1985) Cell-type specificity of immunoglobulin gene expression is regulated by at least three DNA sequence elements. Cell 41: 885-897.

20. Munemitsu S, Innis MA, Clark R, McCormick F, Ullrich A, Polakis P. (1990) Molecular cloning and expression of a G25K cDNA, the human homolog of the yeast cell cycle gene CDC42. Mol. Cell. Biol. 10: 5977-5982.

21. Kitts PA, Ayres MD, Possee RD. (1990) Linearization of baculovirus DNA enhances the recovery of recombinant expression virus. Nucleic Acids Res. 18: 5667-5672.

22. Smith GA, Summers MD, Fraser MJ. (1983) Production of human interferon in insect cells infected with a baculovirus expression vector. Mol. Cell. Biol. 3: 2156-2165.

23. Maiorella B, Inlow D, Shauger A, Harano D. (1988) Large-scale insect cell-culture for recombinant protein production. Biotechnology 6: $1406-1510$.

24. Giese K, Grosschedl R. (1993) LEF-1 contains an activation domain that stimulates transcription only in a specific context of factor-binding sites. EMBO J. 12: 4667-4676.

25. O'Reilly DR, Miller LK, Luckow VA. (1992) Baculovirus Expression Vectors: A Laboratory. Freeman and Company, New York.

26. Wetzel R. (1992) Principles of protein stability. In: Rees AR, Sternberg MJE, Wetzel R (eds). Protein Engineering. A Practical Approach. IRL Press, Oxford.

Contributed by F. E. Cohen on September 21, 1995. 